\title{
Internalizing a novel industrial chain through public financing: the importance of compatibility between technology, local content criteria and objectives in the impaired Brazilian solar expansion
}

\author{
ANDREÃO, Gustavo Onofre ${ }^{a}$ \\ VAZQUEZ, Miguel ${ }^{\text {b,c,d,e }}$ \\ HALLACK, Michelle ${ }^{b, e}$
}

\begin{abstract}
The Brazilian Development Bank (BNDES) has been the main source of funding for wind generation. Its main financing program (Finem) is considered a success in its attempt to promote wind generation in Brazil. Finem is linked to a local content policy that aims to internalize novel industrial chains. It was expected from solar generation to go down a similar successful path, using the same promotion and financing mechanisms as wind power generation. However, this has not been verified. There are several delayed solar power plants and most of them are unlikely to go into operation on schedule, which relates to the maintenance of a national solar PV industry at an underdeveloped state. Therefore, we analyze the incompatibility between technology, the financing methodology (local content requirements) and objectives. For that we: compare solar and wind technical and economic differences; describe the incentive mechanism; and show the results for both sources, relying on data and analysis currently available. For an insertion of solar PV in the matrix and an internalization of this industrial chain in the country, objectives, methodology and technology must be harmonious. Brazil has to decide between a larger deployment of solar PV with imported panels; or a long-term objective with multiple policies towards a reasonable internalization of the chain. A local content criterion aimed at services rather than items might be a third option.
\end{abstract}

Keywords - Photovoltaic, PV, Finance, State Financing, Financing mechanisms, BNDES, Brazil, Internalization, Industrial chains, Local content policies, Finem

JELCodes - G32, L52, Q42, Q48

ABEIN Indicator - 6.1, 6.2

\section{Resumo}

O Banco Nacional de Desenvolvimento Econômico e Social (BNDES) tem sido a principal fonte de financiamento para a geração eólica. Seu principal fundo de financiamento (Finem) é considerado um sucesso em sua tentativa de promover a geração eólica no Brasil. O Finem está ligado a uma política de conteúdo local que visa internalizar novas cadeias industriais. Esperava-se um resultado similar da geração solar fotovoltaica (FV), usando os mesmos mecanismos de promoção e financiamento da geração eólica. No entanto, isso não foi verificado. Existem várias usinas solares com a construção atrasada e é improvável que a maioria delas entre em operação no prazo, o que se relaciona com a manutenção de uma indústria nacional de energia solar FV em um estado subdesenvolvido. Assim, analisamos a incompatibilidade entre tecnologia, metodologia de financiamento (requisitos de conteúdo local) e objetivos. Para isso vamos: comparar as diferenças técnicas e econômicas de solar FV e eólica; descrever o mecanismo de incentivo; e mostrar os resultados para ambas as fontes, de acordo com os dados e análises mais atuais. O Brasil tem que decidir entre uma maior implantação de solar com painéis importados; ou um objetivo de longo prazo com políticas de múltiplos âmbitos para uma internalização razoável da cadeia. Um critério de conteúdo local baseado em serviços em vez de itens pode ser uma terceira opção.

Palavras chave - Energia fotovoltaica, FV, Financiamento estatal, mecanismos de financiamento, BNDES, Brasil, Internalização, cadeias industriais, Política de conteúdo local, Finem

Códigos JEL - G32, L52, Q42, Q48

Indicação de área ABEIN - 6.1, 6.2

\footnotetext{
a Programa de Pós-graduação em Economia of Universidade Federal Fluminense (PPGE-UFF), master's student. Email: gustavo.93.andreao@gmail.com

${ }^{\mathrm{b}}$ Faculty of Economics, Universidade Federal Fluminense (UFF). Campus do Gragoatá - Bloco F - São Domingos - NiteróiRio de Janeiro, Brazil - CEP: 24210-350

${ }^{c}$ IEFE - Bocconi University. Via Röntgen, 1, 20136, Milan, Italy. tel: +39025836 3820.

${ }^{\mathrm{d}}$ CERI - FGV (Center for Regulation and Infrastructure Studies, FGV). Praia de Botafogo, 210/Cob. 01. Rio de Janeiro - RJ Brasil; 22250-145.

${ }^{\text {e }}$ Florence School of Regulation, RSCAS, European University Institute. Via delle Fontanelle, 19, 50014 Firenze, Italy.
} 


\section{Introduction}

Solar PV is a renewable source that utilizes sunlight to produce electricity, without noise or negatively impacting upon the wildlife (unlike wind, an important renewable source) and without emitting greenhouse gas or pollutants (unlike fossil sources, such as gas and oil). Brazil is a country with a largely clean and renewable electricity mix, i.e., its installed capacity. The hydro source is historically important in the country (until the early 2000 's, over $80 \%$ of the mix was composed by hydro), however, a sustainable expansion of hydro plants (with dams) is unfeasible because of environmental problems. Since mid 1990's other sources have begun to grow, however, until mid 2000's, most of this non-hydro expansion was based on fossil-fueled power plants. Afterwards, biomass power generation started to be reasonably introduced into the mix. The Brazilian electricity mix should grow accordingly to the growth in demand for electricity. Moreover, its growth is not only expected but planned by State.

Since the late 2000's, there has been a great expansion of wind power generation in Brazil, planned by the State and performed by private companies. The country successfully inserted wind power generation into its electricity mix, alongside with a reasonable internalization of its value chain. The other important new renewable source, solar PV, should currently be undergoing its first steps towards a similar expansion in the country, according to State planning. Therefore, the same was expected for solar: to be inserted in the mix; while internalizing its industrial chain.

Brazil aims to foment solar farms taking advantage of its high potential for solar energy and the institutional importance of the National Bank of Development ${ }^{1}$ (BNDES) regarding the funding of infrastructure projects. The development of new industrial chains is institutionally tied (through the traditional mechanism) to the development or insertion of the source in the mix. However, most of the Brazilian solar expansion currently has low viability, especially in regards to the schedule and construction rhythm of its already contracted solar farms. Most are not currently under construction, some projects are halted and the few being constructed are actually importing solar PV panels, bypassing the traditional mechanism and not internalizing an important and advanced value chain.

The scope of this work refers to centralized solar photovoltaic (PV) power generation, also known as utility-level solar PV. Brazil relies heavily on a traditional model of generation with large centralized power plants. Moreover, the main objectives of grid-connected centralized and distributed PV generation are different: centralized power generation aims to generate and transmit energy from the power plant to the consumer; whereas distributed power generation aims to reduce the dependence on the grid or the consumption of electricity (from the grid) through self-production and self-consumption. Distributed solar PV involves more types of agents, more complicated mechanisms and tools. Lastly, distributed solar PV is expected to grow at a lower rate and to a lower capacity than its centralized counterpart.

Therefore, we analyze the reasons behind the Brazilian impaired solar PV expansion. As such, this article is divided in five sections, apart from this introduction. In the first section we analyze the technical and economical differences between solar and wind power generation. We then analyze the framework for deployment of renewables in the country. Then we investigate the evolution of solar developments. We then analyze the compatibility between financing mechanisms and financing objectives in regards to the internalization of the chain and the current events. Lastly, we present our closing remarks.

\section{Technical and economical characteristics of the solar and wind sources}

The new renewables ${ }^{2}$ are a rather technologically heterogeneous group. Wind and solar plants generate power through different sources, each having its characteristics and specificities, which we now analyze.

\subsection{Wind Power Generation}

\footnotetext{
1 "Banco Nacional de Desenvolvimento Econômico e Social" in portuguese

${ }^{2}$ Renewables with the exception of hydro power generation, including solar PV, concentrated solar power, wind, bioenergy (including biomass), tides, waves and other novel types of power generation.
} 
Wind energy is a form of kinetic energy, resulting from air pressure differentials due to solar irradiation and geographical characteristics. The wind turbine is the equipment that transforms wind energy in electric power under certain conditions (as wind behavior, direction, velocity, etc.). The amount of generated power is a function of air density, the blade area (covered while spinning) and the wind speed, i.e., capacity factor is dependent on the wind resources, its technical availability and the size of the generator in comparison to the length of the rotor blades. That means that wind turbines can improve its performance through the blade area and by accessing more fast or stable winds (IRENA 2016b; Podcameni 2014; Tolmasquim 2016; US DOE 2014).

Wind turbines are divided by three classifications: regarding its axis direction; its location; and its potency. Regarding the axis direction, it can be vertical or horizontal, being the last one the most used. Regarding its location, the turbines can be located on shore or off shore. Lastly, regarding its potency, there are three sizes of wind turbines: small (up until 0.5 MW); medium (from 0.5 MW to $1 \mathrm{MW}$ ); and large (from $1 \mathrm{MW}$ upwards). This is the one generally used in wind farms ${ }^{3}$ (Podcameni 2014).

In regards to the horizontal axis wind turbine, there are blades (generally three) connected through an axis to a generator inside a component named "nacelle" that can have other components, such as a multiplier box or a gear box. All these components are put on top of a tower, for the wind turbine to access more fast and stable winds ${ }^{4}$ (Podcameni 2014; Tolmasquim 2016; US DOE 2014).

Figure 1 - Cross section of a wind turbine

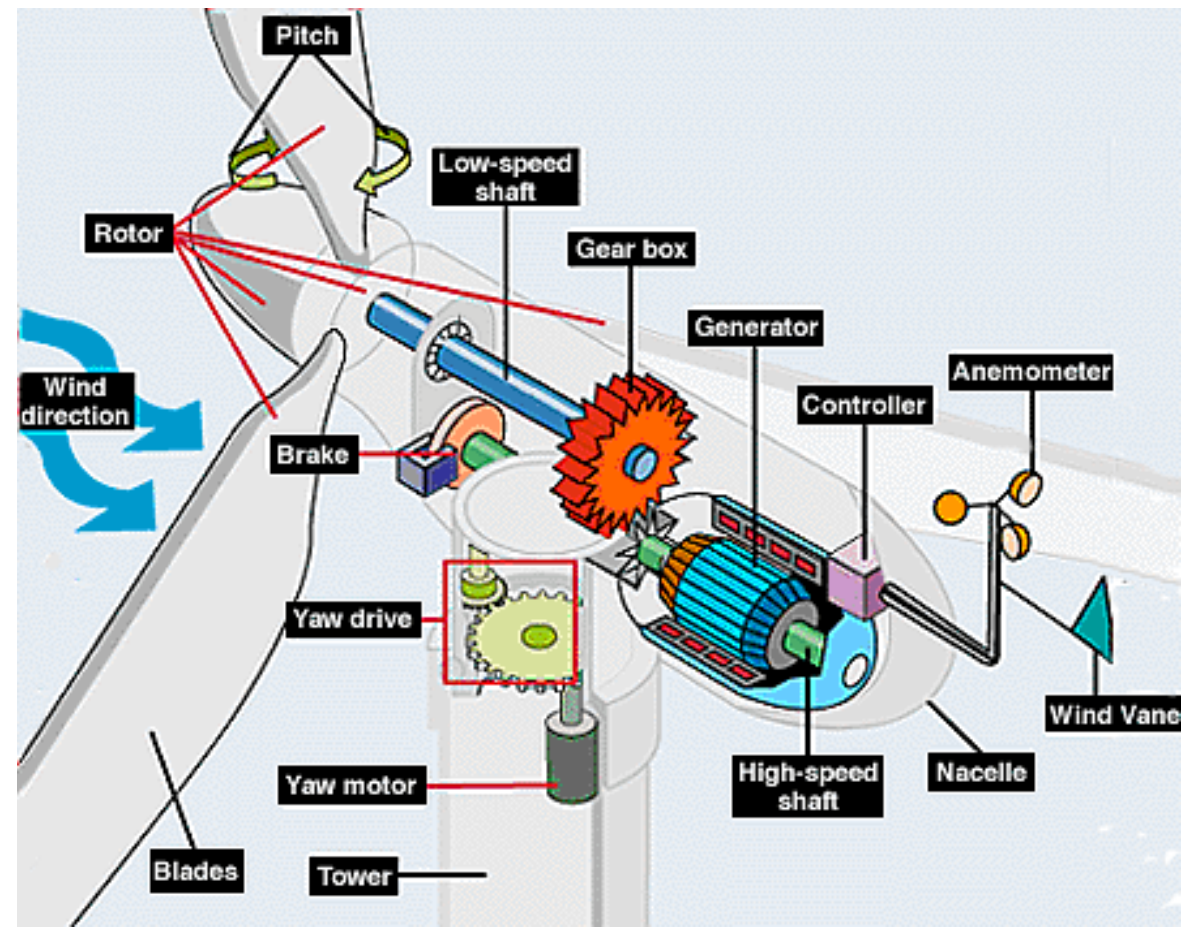

Source: US DOE (2014)

Wind power generation has, like all other sources, pros and cons. Wind turbines need stable and continuously wind speeds to generate electricity. However, a relatively high variability of output (when compared to non-intermittent sources) is common for wind, which can cause disturbances in the grid. However, this is greatly reduced with the geographic dispersion of interconnected wind farms. Wind turbines also disturb the wild life and can cause damages to the environment, which can be diminished through an efficient regulatory framework (IRENA 2016b).

\footnotetext{
${ }^{3}$ Brazil (and most countries) utilizes horizontal, on shore and large wind turbines in its wind farms.

${ }^{4}$ They are positively correlated to the altitude.
} 
The industrial chain of wind turbines is concentrated, largely dominated by large transnational companies. Known as original equipment manufacturers, they often outsource a large option of the manufacturing of parts and equipments related to wind turbines. However, all have, in its country of origin, a still relevant market for their products and most of them were able to grow in size and capture market share through state policies regarding economic viability and innovation. They compose the upstream side or production side chain of equipment. The services or downstream side of the supply chain is comprised by the companies related to the actual deployment and related services (IRENA 2016a; Navigant Research 2016; Podcameni 2014)

Interestingly, out of the all renewables, wind was the only source to experience a rise in concentration of patents among the top 20 organizations. This is likely indicative of the maturity of this technology when compared to solar PV or biofuels. The policies used, spanning industrial, innovative, energy and other classifications were a determinant factor in their entry success and in the maintenance of their prominent position (Podcameni 2014). Wind power generation is considered a well established industry, having a mature technology with a clear technological path defined (Cleantech Group 2016; Helm, Tannock, and Iliev 2014; Huenteler et al. 2016).

We now analyze the characteristics of solar power generation.

\subsection{Solar Power Generation}

Regarding solar PV power generation ${ }^{5}$, sunlight strikes the earth in different ways, and the PV generation depends largely on the diffuse horizontal irradiation (sunlight that goes through clouds, dust, etc.), a part of the horizontal global irradiation. The solar cell is the locus of the photovoltaic effect, which is the transformation of sunlight in electrical energy, generating direct current electricity in each of those $1 \mathrm{~W}$ to $1.5 \mathrm{~W}$ solar cells. Those, which can be made out of different materials, are combined into solar panels (generally up to $250 \mathrm{~W}$ ), being the ones made from silicon the most predominant and widely available types of panels. Silicon panels can be made out of monocrystalline or policrystaline silicon. Silicon solar panels are positively affected by solar irradiation levels and negatively by temperature, although thin film panels are not as affected by it. Thin film panels are cheaper but have less output than its silicon counterpart: they need larger areas for a power generation as effective as silicon panels. This source does not generate noise and has no inertia, which can make the electric power generation range from $\pm 50 \%$ in between 30 and 90 seconds intervals and $\pm 70 \%$ in between 2 and 10 minutes intervals. However, like wind power generation, the dispersion of solar farms can largely reduce this variability. Unlike the previous case, solar PV does not have moving parts (ABSOLAR 2016; EPE 2012; Green and Staffell 2016; Januzzi 2009).

Solar power generation can: be on-grid or off-grid (in regards to it being or not connected to the electrical grid respectively); and centralized or distributed (off-grid capacity cannot be centralized). The last division is more relevant to the subject, as centralized solar PV has generally a larger capacity (and therefore output) than distributed solar PV, and the panels are ground-mounted instead of assembled on rooftops, which is generally the case for distributed solar PV. There is also a large reduction of costs associated with centralized, or utility-level solar PV. Also, the purpose of the generation changes: while distributed solar PV aims to lessen the dependence of the household, commercial or industrial facility of the grid, centralized solar PV is inherently connected, producing electricity to be put into the grid, similar to other power plants. When on-grid systems are used, there needs to be a conversion from direct current to alternate current, through inverters. Also, on-grid solar power generation cannot fully substitute other generation sources, because of its intermittence. However it can be used in place of more costly or polluting sources $^{6}$ (EPE 2012; Green and Staffell 2016; IEA 2015; Tolmasquim 2016).

\footnotetext{
${ }^{5}$ We do not analyze heliothermic power generation, which uses solar irradiation to generate heat, which in turn generates steam that powers a steam turbine, rather similar to other thermic power plants. Utilizations of sunlight for heat purposes are also disregarded.

${ }^{6}$ At least until storage is not a possible or practical solution in large scale.
} 
Figure 2 - Solar PV Value Chain - World

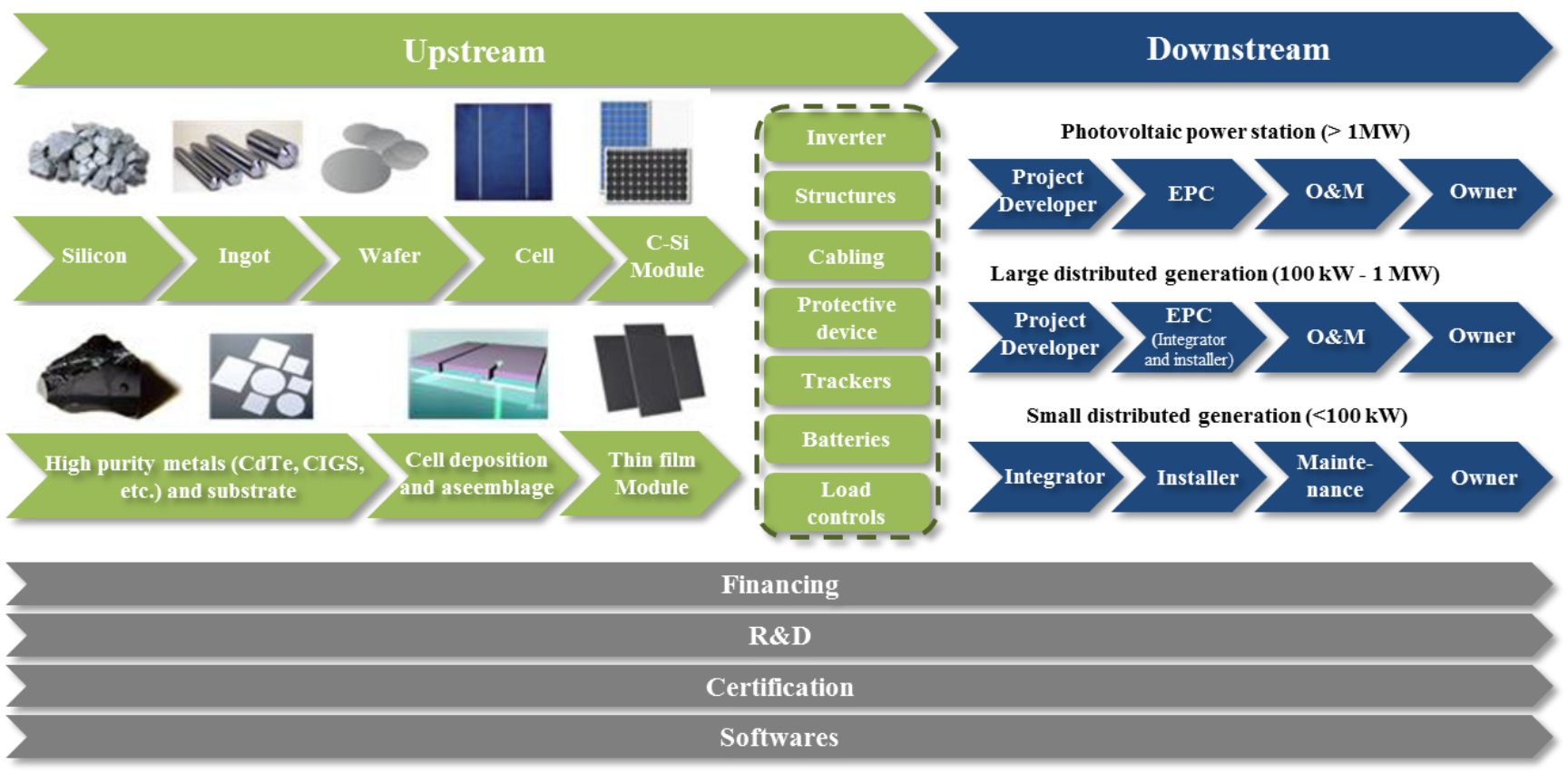

Source: Adapted from Tolmasquim (2016)

The value chain of solar PV can be divided into upstream and downstream, respectively: production of overall components of the PV system (modules, equipment and necessary accessories); and services associated with the implementation of the solar PV projects. The PV system is composed of solar cells that are aggregations of wafers, which are composed by ingots and lastly by silicon ${ }^{7}$. For PV plants, the downstream side of the supply chain can be subdivided into: project developer; engineering, procurement and construction; operation and maintenance; and ownership (Tolmasquim 2016).

EPE (2012) divides it into five segments: raw material production, i.e., making of metallurgic grade silicon out of quartz; refinement, i.e., production of solar grade silicon; treatment, generating wafers, solar cells and PV modules; complementary equipment, such as batteries, converters, inverters and brackets; and lastly, application, i.e., generating power. An increase in thin film solar panels participation among the total is expected, however, silicon based panels will maintain its major importance in the near future.

Refining metallurgic grade silicon (below 99\% purity) to solar grade (about $99.9999 \%$ purity) is generally done through the energy intensive Siemens process, producing a toxic and corrosive waste. The energy costs are responsible for $25 \%$ of the total in such process. This stage is much more concentrated than all other stages in this already concentrated chain. Brazil has large high quality quartz reserves and already holds refining industries, albeit they only can refine up to metallurgic grade silicon (less pure than solar grade silicon). Brazil is currently unable to mass produce solar grade silicon (EPE 2012).

Latin America, unlike Europe, began its solar expansion with centralize or utility-level PV, mainly because of cost-related issues and the fact that less players with larger output are easier to coordinate through auction mechanisms (common in the region). Also, the distributed solar PV is expected to follow the growth of centralized solar PV, i.e., utility-level solar PV is expected to lead the way regarding the expansion of the source (GTM Research 2016; IEA 2015).

Brazil has a great daily average solar irradiation number per year, which is a strong incentive in the promotion of such source. Also, the solar resource in Brazil is well distributed countrywide, and the solar potential is higher than the wind potential, in regards to power generation. The worst area regarding

\footnotetext{
${ }^{7}$ We refer to the major technology deployed: crystalline solar grade silicon.
} 
PV power generation in Brazil $\left(1500\left(\mathrm{kWh} / \mathrm{m}^{2}\right) /\right.$ year) is greater than the German average (1250 $\left(\mathrm{kWh} / \mathrm{m}^{2}\right) /$ year$)$. There is a possibility of coordination and integration between solar power generation and hydro power generation, the most relevant source in the country for power generation. The Brazilian solar resource also has an intra-year variability lower than that observed in hydro and wind generation. The best irradiation numbers (regarding average irradiation and cloudiness) appear on the northeastern region of Brazil, and the worst on its southern region ${ }^{8}$ (ABSOLAR 2016; EPE 2012; Pepitone 2016).

Solar PV is the top researched renewable technology (while compared to wind, bioenergy, and solar thermal): currently, solar PV is responsible for $41 \%$ of patent filings worldwide. According to Helm, Tannock and Iliev (2014), among the top 20 renewable technology owners (in terms of patents) 15 organizations are related to solar PV. In Latin America, renewable technology dominates the climate change mitigation technologies patent filings, but solar PV only accounts for less $1 \%$ of the total. Brazil is the most important country in terms of patents in Latin America, with over $50 \%$ of all climate change mitigation technologies patent filings in the region (Helm, Tannock, and Iliev 2014; UNEP and EPO 2014).

Unlike wind power generation, solar PV is not considered a mature industry. The number of patent filings comprises the largest number of patent filings in the most relevant patent offices (United States, Japan and Europe ${ }^{9}$ ). There is still no clear technological path or design path defined for solar PV, as indicated by the large types of technologies commercially used and in research state ${ }^{10}$ (Cleantech Group 2016; Eurostat 2017; Helm, Tannock, and Iliev 2014; MITEI 2015).

Having differentiated between the both sources, we now analyze the current incentive framework for a larger deployment of renewables.

\section{The Current Brazilian framework to promote renewables}

Brazil is a country with favorable numbers and projections for most renewable sources: it largely uses hydro power; it is promoting wind power generation in a rapidly growing context; and is now starting to promote solar power generation. Historically, Brazil largely depended on hydro power: most of its capacity until the reforms of the 1990's was constituted of large hydro power plants with large dams. In the period before the reforms, the State: owned much of the capacity; owned much of the assets; and vertically planned, executed and implemented the expansion of the mix (Almeida and Bicalho 2014; EPE 2014; Pinto Junior 2007).

Since $2004^{11}$ there has been a resumption of medium and long term planning in the Brazilian electrical sector after a problematic reform which happened since the early 1990's until early 2000's (Joskow 2008; Pinto Junior 2007). There is a real possibility of a clean and sustainable expansion of the Brazilian electric mix by expanding towards renewables (Pepitone 2016; Campos Neto 2016). That complies with the maintenance of a clean Brazilian energy mix (Almeida and Bicalho 2014) ${ }^{12}$ and follows the international move towards a more renewable and sustainable electric mix (Green and Staffell 2016; Podcameni 2014).

There are two severe problems with the promotion of renewables in Brazil: on the spot market; and on the stock market. Both problems are solved with state solutions: through generation auctions; and through public financing. State planned auctions play an important role in the current expansion of Brazil's installed capacity, especially by attenuating the problems related to the intermittence of renewable sources. Also, through the auction tool, the winners access special state financing lines. This is

\footnotetext{
${ }^{8}$ The northeastern region is at the same time adequate for solar and wind power generation in the country, which could lead to a regional development related to energy, especially if the value chains were implanted in the region.

9 The State Intellectual Property Office of the People's Republic of China has the larger number of solar PV patent filings among others patent offices. However, there are some quality problems related to a significant number of Chinese patents, with most being due to policies regarding foreign direct investment rather than R\&D (Reuters 2011; Hu and Jefferson 2009).

${ }^{10}$ MITEI (2015) analyzes the possibilities and different technology paths available and in research for solar PV.

${ }^{11}$ According to Campos Neto (2016), the expansion of renewables, except hydro, is fairly recent in Brazil, starting in mid to late 2000's.

${ }^{12}$ The authors emphasizes the promotion of new renewables, especially, solar and wind power generation.
} 
cardinal in order to promote infrastructure in the country (Ferraz 2015; Pepitone 2016; Vazquez 2015). According to IEA (2015), the traditional forms of renewable finance are: recycling of capital into new projects; utility restructuring; shift to renewables due to emissions policies; project finance structures; and development banks. In Brazil, for renewables, the development bank as a way of financing the deployment of renewables is a key driver for a larger share of non-fossil sources in its electric matrix, e.g. wind.

Essentially, state auctions guarantee the offer, i.e. the capacity, by assuring the demand for the auction winners, whereas state financing permits that, once the offer is secured, the contracted capacity has the means to be developed in schedule. Therefore, it is expected from the new renewables to be promoted through State planning and funding. Through the latter tool (public financing), industrial policy is executed: a progressive internalization of novel industrial chains is intrinsically linked to the access criteria of public funds through a local content policy. Those the current incentive mechanisms for the expansion of the electric mix (IEA 2015).

According to the State planning for $2024^{13}$, the wind farms installed capacity will add up to 24 GW, and the solar farms installed capacity will add up to $7 \mathrm{GW}$ (EPE, 2015). In April 2017, 10.4 GW $(6.83 \%)$ and $27 \mathrm{MW}^{14}(0.02 \%)$ were the numbers for, respectively, solar and wind sources installed capacity, and 2,163 GWh (3.72\%) and $59 \mathrm{GWh}(0.01 \%)$ were the numbers for the power generation in 2015 (ANEEL 2017a; EPE 2014, 2016a).

We now analyze their roles, first the auction tool, then the state financing tool.

\subsection{Incentives by market Design: auctions}

The first half of the Brazilian framework for promoting the expansion of its installed capacity is an auction mechanism for power generation ${ }^{15}$. It emphasizes ex-ante competition, selecting competitive projects. Auctions mitigate risk and facilitate the access to state funds regarding infrastructure investments (Ferraz 2015).

There are different auctions depending on its objective. Its main auctions are those aimed for new projects. The most common types are A-3 and A-5 auctions, i.e., auctions happening three or five years prior to the auctioned plants commercial operation. Several wind farms were auction winners on those, in which there is open competition between all sources. Wind power generation in Brazil is therefore, currently competitive when in comparison with its rival sources (Pinto Junior 2007).

Nevertheless, its history of generation auctions begun with the more specialized types, aimed at promoting underdeveloped sources. Wind farms have been present in auctions ever since the Reserve Energy Auction $\left(\mathrm{LER}^{16}\right.$ ) of March 2009. This type ${ }^{17}$ is aimed at enhancing the safety of the Brazilian power system, and, by scaling down the competition; it is easier for incipient sources to win. Therefore, $\mathrm{it}^{18}$ is best suited for incipient sources of undeveloped industrial chains, such as the wind power was in the late 2000's and the solar power currently is. From 2009 until 2016, there were 509 wind farms contracted, spanning 13,370.45 MW of contracted capacity (ANEEL 2016d).

Solar farms are currently in an undeveloped state, with only three auctions (all of them LER auctions), with 94 plants and 2,652.8 MW of installed capacity contracted. Also, from the first to the last

\footnotetext{
${ }^{13}$ Known as "Plano Decenal de Expansão de Energia 2014-2024" in portuguese, which is a 10-year plan on the Brazilian energy sector approved by the country's Ministry of Mines and Energy (EPE 2014).

14 The solar PV capacity displayed by ANEEL (2017a) takes into account also the little distributed solar PV that there is in Brazil. Out of it, only $10 \mathrm{MW}$ could be considered "utility-level solar PV" because of the capacity (over $5 \mathrm{MW}$ according to GTM Research (2016)), all belonging to two power plants that belong to Enel Green Power: Fontes Solar I and Fontes Solar II. Both however, were not contracted through a federal auction, rather through an auction promoted by the northeastern state of Pernambuco (Governo de Pernambuco 2013). However, to ANEEL (2016g, 2017b) there's no utility-level solar PV capacity.

15 There are also transmission auctions, which we do not analyze.

${ }^{16}$ Acronym for "Leilão de Energia Reserva" in portuguese.

17 For more information on Brazilian power auctions, we suggest readers to check ANEEL's explanation on them: http://www.aneel.gov.br/resultados-de-leiloes

${ }^{18}$ Alongside the rarely used Alternative Sources Auction (“Leilão de Fontes Alternativas” in Portuguese).
} 
auction, the average MWh price has fallen from US\$ 88 to US\$ 78 according to ABSOLAR (2016). Specific solar auctions are a major incentive in the promotion of the solar source generation ${ }^{19}(\mathrm{Januzzi}$ 2009; Sekiguchi 2014). They also incentivize the internalization of its industrial chains (of parts, components and also assembly processes) by assuring the demand. Annually solar auctions (LERs) adding up to 1 additional GW per year were expected, being this the least necessary for structuring a supply chain in Brazil, however, there were no solar capacity contracted in $2016^{20}$ (ABSOLAR 2016; Ferraz 2016; SITAWI and CEBDS 2016).

Among the companies that won the three auctions involving PV generation, LER 08/2014, LER 08/2015 and LER 09/2015, the four main companies together have 52.12\% (49 units) of all solar power plants and 54.13\% (1,419.9 MW) of all installed capacity. Those are: the Italian group Enel; Canadian Solar Inc; Lintran do Brasil Participações S.A., a subsidiary of a Spanish company; and the French Solairedirect.

Table 1 - Contracted capacity of Solar PV at LER Auctions - MW, \%, R\$ 1000 - Brazil - 2015-2016

\begin{tabular}{|c|c|c|c|c|c|}
\hline \multirow{2}{*}{ Companies } & \multicolumn{2}{|c|}{ Plants } & \multicolumn{2}{|c|}{ Potency } & \multirow{2}{*}{$\begin{array}{l}\text { Investment in Nov. } \\
2016 \text { R \$ (IGP-M) } \\
\text { R\$ } 1,000.00\end{array}$} \\
\hline & Units & $\%$ & MW & $\%$ & \\
\hline Enel & 22 & $23.40 \%$ & 619.98 & $23.64 \%$ & $\mathrm{R} \$ 4,037,939.82$ \\
\hline Canadian Solar Inc & 11 & $11.70 \%$ & 329.97 & $12.58 \%$ & $\mathrm{R} \$ 1,559,566.51$ \\
\hline $\begin{array}{c}\text { Lintran do Brasil Participações } \\
\text { S.A. }\end{array}$ & 9 & $9.57 \%$ & 269.97 & $10.29 \%$ & $\mathrm{R} \$ 1,356,888.48$ \\
\hline Solairedirect SAS & 7 & $7.45 \%$ & 199.98 & $7.62 \%$ & $\mathrm{R} \$ 953,189.81$ \\
\hline Sune Solar B.V. & 5 & $5.30 \%$ & 148.57 & $5.66 \%$ & $\mathrm{R} \$ 651,463.56$ \\
\hline Renova Energia S.A. & 5 & $5.32 \%$ & 129.59 & $4.94 \%$ & $\mathrm{R} \$ 722,581.38$ \\
\hline STEELCON & 3 & $3.19 \%$ & 90.00 & $3.43 \%$ & $\mathrm{R} \$ 651,380.27$ \\
\hline $\begin{array}{c}\text { Rio Energy EOL IV Geração e } \\
\text { Comercialização de Energia } \\
\text { Ltda }\end{array}$ & 3 & $3.19 \%$ & 89.91 & $3.43 \%$ & $\mathrm{R} \$ 495,023.23$ \\
\hline European Energy A/S & 2 & $2.55 \%$ & 60.00 & $2.29 \%$ & $\mathrm{R} \$ 384,312.92$ \\
\hline $\begin{array}{l}\text { Fotowatio do Brasil Projetos de } \\
\text { Energia Renováveis III Ltda. }\end{array}$ & 2 & $2.13 \%$ & 60.00 & $2.29 \%$ & $\mathrm{R} \$ 329,456.84$ \\
\hline SPE CESP COREMAS & 2 & $2.13 \%$ & 60.00 & $2.29 \%$ & $\mathrm{R} \$ 303,340.31$ \\
\hline Grupo Gransolar S.L. & 2 & $2.13 \%$ & 60.00 & $2.29 \%$ & $\mathrm{R} \$ 274,736.11$ \\
\hline Kawa & 2 & $2.13 \%$ & 54.00 & $2.06 \%$ & $\mathrm{R} \$ 263,639.82$ \\
\hline $\begin{array}{c}\text { Companies with less than } 50 \\
\text { MW of contracted capacity } \\
\text { (38) }\end{array}$ & 19 & $19.82 \%$ & 450.93 & $17.19 \%$ & $\mathrm{R} \$ 2,714,478.01$ \\
\hline Total & 94 & $100 \%$ & 2622.89 & $100 \%$ & $\mathrm{R} \$ 14,697,997.07$ \\
\hline
\end{tabular}

Source: Own elaboration based on ANEEL (2016d)

Just the two biggest companies regarding capacity (Enel and Canadian Solar Inc) have almost 1 GW of planned capacity combined. From this, regarding power plants and capacity, these companies are

\footnotetext{
19 According to Moreno and Weiss (2016), the solar source in Brazil is currently one of the less competitive generation sources. This is due to the high internal costs of its components and to a still low capacity factor.

${ }^{20}$ The $1^{\text {st }}$ LER of 2016 did not contract solar PV power plants, and the $2^{\text {nd }}$ LER of the year was canceled due to disinterest of agents and a reduction of the National Interconnected System (the grid) charge.
} 
extremely important to the promotion of solar power generation in Brazil. The contracted capacity was expected to enter into operation between 2017 and 2019.

Therefore, between 2014 and 2015, solar PV was successfully inserted into the auctions in Brazil, selecting winners (at reasonable and competitive prices). The contracted capacity had an assured demand, and was therefore guaranteed. This indicates that part of the incentive framework for solar PV functioned between 2014 and 2015 (ANEEL 2016d, 2016g).

However, in 2016, no solar PV capacity was contracted. In 2016 there was only one LER, which contracted run of the river small hydro plants and thermoelectric plants. The second LER was delayed and then canceled, because of a decrease in the demand for electricity (EPE 2016c, 2016b).

Having analyzed the auction mechanism, we now analyze the financing mechanism in the following section.

\subsection{Incentives by financing mechanisms: the role of the Brazilian Development Bank}

BNDES plays an important role regarding the infrastructure sector in Brazil, including the electrical sector, in regards to financing and funding ${ }^{21}$. BNDES' financing lines have lower interest taxes than most private financing mechanisms. Brazil has one the highest real interest rates of the world ${ }^{22}$, therefore access to its funds is essential to most infrastructure projects in Brazil. Consequently, it is the most prominent financing mechanism in the country.

The Finem (Financing to Enterprises) ${ }^{23}$ fund is the most important financing tool for infrastructure (and therefore, power) of BNDES. Regarding wind farms, it is especially important, rising in disbursements as this source began to gain importance in the auctions. It has financed up to $90 \%$ of the installed capacity of wind power generation (Campos Neto 2016; SITAWI and CEBDS 2016; Tomelin 2016).

BNDES, through its financing mechanisms, actively promotes the internalization of industrial chains, i.e., it exercises industrial policy through local content criteria. The bank has strict access criteria in terms of local content requirements. Those are progressive, starting on easier (regarding technology, costs and other factors) levels and moving up to more technologically developed (and therefore challenging) levels. There are also means of monitoring if one is respecting the required levels of local content, that are different for each source. This is basically done through the "Computerized Manufacturers Accreditation" 24 (CFI): the component seller company must be accredited there (Ferreira 2013; Podcameni 2014).

BNDES is also one of the few banks or organizations in Brazil that operates with long-term financing, which is key for the viability of infrastructure projects such as energy projects. Development banks, such as BNDES, are also capable of promoting great transformations in the economy through public policy. Mission-oriented state investment banks are also an important tool for still incipient and underdeveloped markets and sectors, such as solar PV (Mazzucato and Penna 2016, 2015)

The required segments in the production of parts or its assembly must be done inside the Brazilian territory by national or multinational companies. BNDES has a fine tuning to do: too high of a local content requirement and the companies will not be able to access its funds; too low of a local content requirement and the national industry will not be incentivized through it.

Solar and wind sources have different access criteria and methodologies. We now briefly analyze them.

\subsubsection{Financing wind power generation}

\footnotetext{
${ }^{21}$ For an analysis of the institutional development of BNDES, we recommend Mazzucato and Penna (2015).

${ }^{22}$ For a comparison, we recommend the Trading Economics (2017) database.

23 "Financiamento a empreendimentos" in portuguese.

24 "Credenciamento de fabricantes informatizado" in portuguese.
} 
According to Sitawi and CEBDS (2016), from 2003 to 2014, BNDES has financed 47,236 MW and 4,912 MW of energy and wind projects, respectively. Focusing on weight and parts, the local content criteria for accessing BNDES' fund to finance wind turbines is already on its last phase as of January $1^{\text {st }}$ 2016. The bank has financed about $90 \%$ of the Brazilian wind installed capacity (BNDES 2012; Tomelin 2016).

Regarding the actual funding, BNDES fixes its maximum participation on $70 \%$. The financing can be done directly through BNDES, with an interest rate between $9.4 \%$ and $13.86 \%$ per year (a fixed $7.5 \%$ of Long term interest rate $\left(\mathrm{TJLP}^{25}\right)$ of Brazil and a margin for BNDES) for companies. For indirect financing, done through a financial institution accredited by BNDES, besides the TJLP and the BNDES' margin, there is also a rate negotiated between the organization and the client. The amortization period is 16 years and there are collaterals for all modalities (BNDES 2017b)

We now analyze the financing mechanism of solar power generation in Brazil.

\subsubsection{Financing solar PV power generation}

With a mechanism heavily inspired by BNDES' prior successful attempt at financing wind power generation (BNDES 2014a), it lets go of the weight and parts criteria, introducing a more sophisticated method: $\mathrm{N}$ factor. This number is achieved by adding up the individual percentages of items and processes. BNDES financial support is equal to its maximum participation percentage $\left(80 \%{ }^{26}\right)$ multiplied by the $\mathrm{N}$ factor. Higher $\mathrm{N}$ factors lead to larger BNDES' participation. Such change was done allegedly to permit a more flexible internalization of this industrial chain. Similar to the financing of wind farms, it can be done directly through BNDES, with an interest rate between $9.4 \%$ and $13.86 \%$ per year (a fixed $7.5 \%$ of TJLP and a margin for BNDES) for companies. For its indirect counterpart, done through financial institutions accredited by BNDES, besides the TJLP and the BNDES' margin, there is also a rate negotiated between the organization and the client. The amortization period is 20 years and there are collaterals in both direct and indirect modalities (BNDES 2014b, 2014a, 2017b).

Regarding the access criteria (BNDES 2014b), it differentiates between thin film and silicon solar panels, and also has a criteria for solar systems. There are three kinds of items: basic, optional and premium. Basic items must be made out of national components or processes, respecting each individual $\mathrm{N}$ factor. Optional items and premium items are not part of the obligatory items required for access, however, their $\mathrm{N}$ factor is added up to the total $\mathrm{N}$ factor of the enterprise ${ }^{27}$.

The bank differentiates between silicon solar panels and thin film panels. Its methodology also differentiates the $\mathrm{N}$ factors for the panels and the whole PV system (module, electrical components, structures and the inverter). The $\mathrm{N}$ factors ${ }^{28}$ range from $40 \%$ to $82 \%$ between the first and the last period(BNDES 2014b).

As of April $2017^{29}$, no solar PV Power plants were financed by the bank, following the similar scenario of 2016. The funding of power plants is linked to the internalization of its industrial chain. In 2016, no national manufacturer was able to provide panels for those enterprises. In May 2016, BNDES expected to have, until the end of the year, three manufacturers in the country able to produce panels according to the local content criteria. In the second semester of that year, Canadian Solar Inc started to

\footnotetext{
25 "Taxa de Juros de Longo Prazo" in portuguese. For an analysis of the evolution of the TJLP, we recomend Ipeadata (IPEADATA 2017).

${ }^{26}$ In 2016, the bank increased its participation in renewable energy projects (to $70 \%$ in wind and $80 \%$ in solar) and decreased its participation in non-renewable projects (Bloomberg 2016). According to BNDES (2017a) solar PV will have a maximum participation of $70 \%$ in regards to the TJLP interest rate. The additional $10 \%$ of financing will be provided by debentures.

${ }^{27}$ The difference between the last two is that optional items add up its $\mathrm{N}$ factor after being incorporated into the solar module, whereas premium items do it before. The reason for such differentiation is that premium items are more technologically advanced or costly than optional items, and therefore harder to internalize.

${ }^{28}$ For more specific information on the matter, we strongly suggest the reading of BNDES (2014b).

${ }^{29}$ The first disbursements of BNDES towards solar PV contracted capacity are currently being analyzed. If approved, they will encompass the first capacity of auction contracted solar PV to be financed by the bank, three years after the first auction and the elaboration of an specific methodology (Reuters Brasil 2017b).
} 
build its first production facility in the country, according to local criteria, i.e., the factory located in Sorocaba, São Paulo (southeastern region) is able to provide modules that could be financed by the bank. Completed in December 2016, it is able to produce up to $350 \mathrm{MW}$ of solar modules, which will be used solely in its own projects for the first six months of production. Afterwards, $250 \mathrm{MW}$ will be reserved for the company's projects and $100 \mathrm{MW}$ will be allocated for other developers. However, in January 2017, the local content requirements were supposed to be increased. The facility was not developed to produce solar modules according to the local content criteria of 2017, but accordingly to that of 2016. If the local content requirements are then increased (which is currently under analysis of BNDES), the economical viability of the facility will be highly jeopardized: the domestic panels are at least $15 \%$ more expensive than Chinese panels. Therefore, the current situation of the traditional financing mechanism is highly uncertain and deficient. (Canadian Solar Inc 2016; Reuters 2016; SITAWI and CEBDS 2016; Reuters Brasil 2016; Bloomberg 2016; BNDES 2014c; PV Magazine 2016; Reuters Brasil 2017a).

Having analyzed the two tools which compose the mechanism for promoting renewables in Brazil, we now review the attempted solar expansion.

\section{Development of solar power generation in Brazil: the evolution of investments}

According to the auction's results, up until September $2016^{30}$ there were $2652.8 \mathrm{MW}$ contracted for commercial operation beginning in 2017 and 2018. However, the figures clash with the planned expansion (ANEEL 2015, 2016b, 2016d, 2016a, 2016c, 2016f).

Table 2 - Forecasts for entry into operation - 2017-2019 - Brazil

\begin{tabular}{|c|c|c|c|c|c|c|c|c|c|c|}
\hline & \multicolumn{3}{|c|}{2017} & \multicolumn{3}{|c|}{2018} & \multicolumn{3}{|c|}{2019} \\
\hline & & $\begin{array}{l}\text { No } \\
\text { restrictions }\end{array}$ & $\begin{array}{c}\text { Some } \\
\text { restrictions }\end{array}$ & Total & $\begin{array}{c}\text { No } \\
\text { restrictions }\end{array}$ & $\begin{array}{l}\text { Some } \\
\text { restrictions }\end{array}$ & Total & $\begin{array}{l}\text { No } \\
\text { restrictions }\end{array}$ & $\begin{array}{l}\text { Some } \\
\text { restrictions }\end{array}$ & Total \\
\hline \multirow{2}{*}{$\begin{array}{l}\text { Capacity } \\
\text { (MW) }\end{array}$} & $\begin{array}{c}2016 \\
\text { Forecast } \\
\text { (MW) }\end{array}$ & 202.00 & 885.99 & 1087.99 & 0.00 & 1029.47 & 1029.47 & 0.00 & 835.66 & 835.66 \\
\hline & $\begin{array}{c}2017 \\
\text { Forecast } \\
\text { (MW) }\end{array}$ & 483.40 & 0.00 & 483.40 & 580.00 & 971.46 & 1551.46 & 0.00 & 506.00 & 506.00 \\
\hline \multirow{2}{*}{$\begin{array}{c}\text { Difference } \\
\text { between } \\
\text { both } \\
\text { years }\end{array}$} & $\Delta(\mathbf{M W})$ & 281.40 & -885.99 & -604.59 & 580.00 & -523.47 & 521.99 & 0.00 & -835.66 & -329.66 \\
\hline & $\%$ & $139.31 \%$ & $-100 \%$ & $-55.57 \%$ & - & $-5.63 \%$ & $50.70 \%$ & - & $-100 \%$ & $-39.45 \%$ \\
\hline
\end{tabular}

Source: Own elaboration based on ANEEL (2016g, 2017b)

Regarding the viability of enterprises, table 2displays a concerning figure: only $7.34 \%$ of all planned solar capacity had no restrictions for entering operation in 2017 according to the conditions in 2016. This accounted for $202 \mathrm{MW}$ out of the 2,953.1 MW expansion expected for 2017-2019 period. According to the 2016 forecast, all remaining capacity had some restrictions to enter into operation when scheduled (ANEEL 2016g).

The revision of 2017 showed a less problematic situation in which the capacity expected to enter into commercial operation that year (2017) has more than doubled: from $202 \mathrm{MW}$ to $483.4 \mathrm{MW}$. This means that 2017 has no solar PV capacity with restrictions. However, it is clear that the capacity previously forecasted to enter into operation in 2017 was relocated to 2018, if not given the "no forecast" status. Therefore, there are still problems in solar PV as of the 2017. For 2018, the capacity with no restrictions forecasted to enter into operation accounted for $580 \mathrm{MW}$ of solar capacity likely to enter into

\footnotetext{
${ }^{30}$ From September on there were later auctions, but none had solar farms as winners(EPE 2016b, $\left.2016 a\right)$.
} 
operation when scheduled. In sum, out of the $2980 \mathrm{MW}$ forecasted to enter into operation between 2017 and 2019, only $35.67 \%$ (1063.4 MW) of all solar capacity had no restrictions to enter into operation when scheduled. The capacity with some restrictions to enter into operation remains the larger out of the three groups (without restrictions, with some restrictions and with severe restrictions): 2,751.1 MW (93.16\%) and 1,477.5 MW (49.57\%) respectively in 2016 and 2017. The capacity with severe restrictions, 439.66 MW, has no forecast to enter into operation (between 2017 and 2020) and accounts for 14.75\% of all solar PV capacity. In 2016 there was no solar PV without forecast to entry into operation, nor any solar PV capacity with severe restrictions to enter into operation when scheduled (ANEEL 2016g, 2017b)

ANEEL (2015, 2016c, 2016f, 2016a) analyze the expansion of planned plants by: viability (probability of entering operation on schedule); schedule (how close the construction is to its schedule); and progress of construction (if they are on construction or not, or halted).Analyzing the commitment to schedule and the progress of construction of the Brazilian solar plants, the numbers are concerning: until October 2016 there were no plants with an advanced schedule; and until the same month there were no plants under construction (ANEEL 2016g, 2016f).

\section{Graph 1 - Solar Farms entry forecast - MW - November 2015 to April 2017 - Brazil}

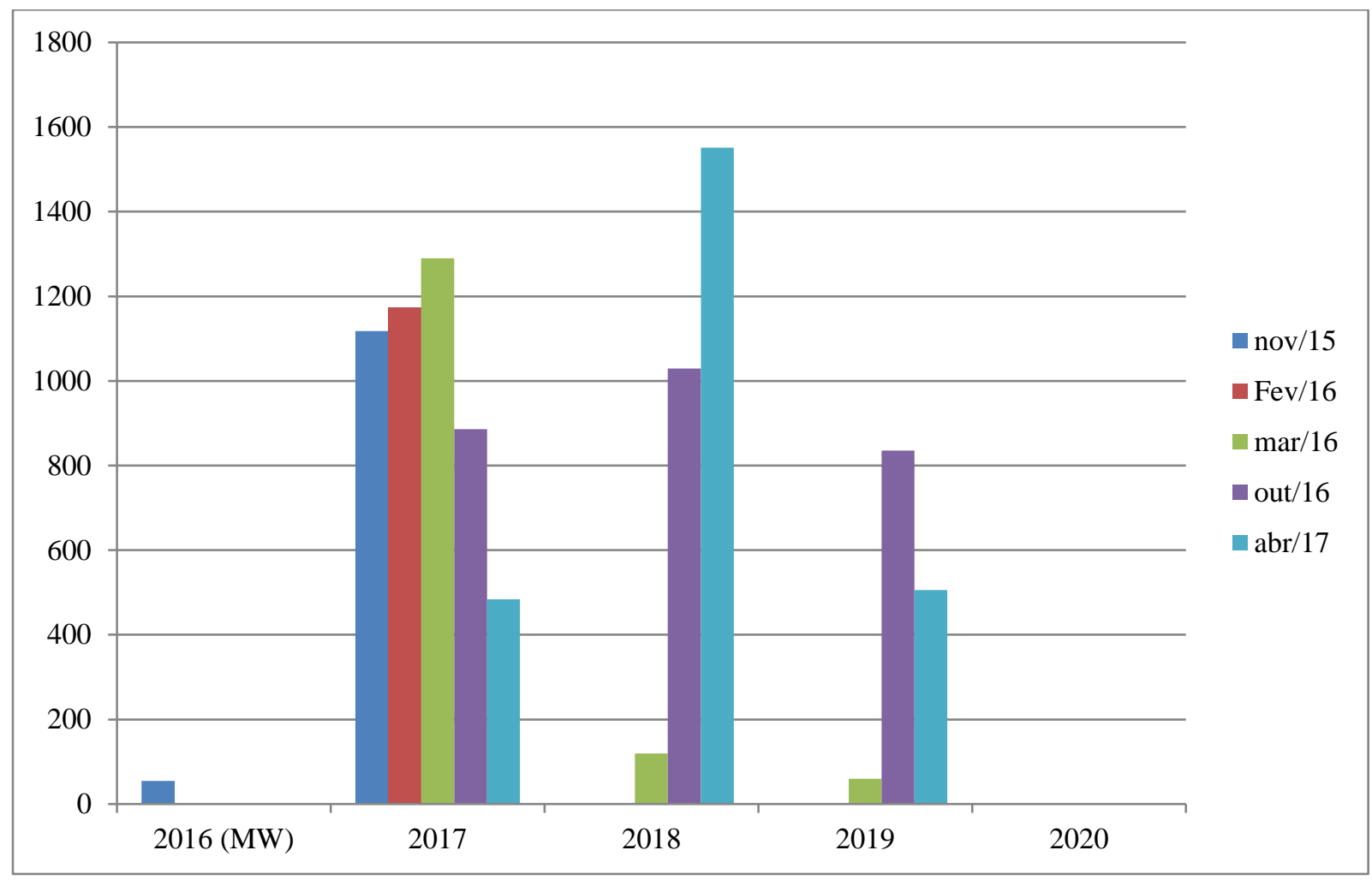

Source: Own elaboration based on ANEEL (2015, 2016a, 2016c, 2016f, 2017d)

At November 2015the review appointed that there were 55 MW scheduled for commercial operation in 2016 (ANEEL 2015). All the capacity was revised to enter operation in 2017 as of the February 2016 report (ANEEL 2016a). At the October 2016review (ANEEL 2016f), there were 9 plants under construction (270 MW total), with only 6 of them also with high viability (180 MW) and only 5 also with an advanced schedule (150 MW): before, no plants were under construction. All 9 plants were owned by the Enel Green Power. In April 2017, the number of solar power plants under construction grew to 37 plants (1063.4 MW), however, the plants not construction are still the majority, with 86 plants (1917.15 MW)(ANEEL 2017d). From table 2 and graph 1 it becomes clear that the solar PV capacity is being consecutively postponed on each review.

Out of the $2.9 \mathrm{GW}$ of planned installed capacity expansion only $9.14 \%$ were under construction ( $8.91 \%$ of all planned solar farms) as of October 2016. In contrast with wind power generation, in 
October $2016,2,910.4 \mathrm{MW}$ or $34.78 \%$ of the capacity were under construction $(34.82 \%$ of plants, or 49 wind farms) and $15.61 \%$ of the plants had an advanced schedule. In April 2017, out of the $3 \mathrm{GW}$ planned expansion, only $35 \%$ were under construction, however, $60.22 \%$ of all solar PV capacity had a delayed schedule. Again, in comparison with the wind source, in April 2017, $3091.5 \mathrm{MW}$ (41.13\%) of the capacity was under construction (145 power plants), and $40.84 \%$ of the capacity $(3,070 \mathrm{MW}$ ) had no restrictions to enter into operation accordingly to schedule. Lastly, out of the total capacity of all sources with restrictions to enter into operation by 2018 and 2019 (5,178.4 MW), solar PV power plants constitute almost 30\% of the total (1,477.46 MW)(ANEEL 2016e, 2016f, 2017d, 2017c, 2017b).

\section{Graph 2 - Solar PV capacity regarding its schedule to enter into operation - MW - November 2015 to April 2017 - Brazil}

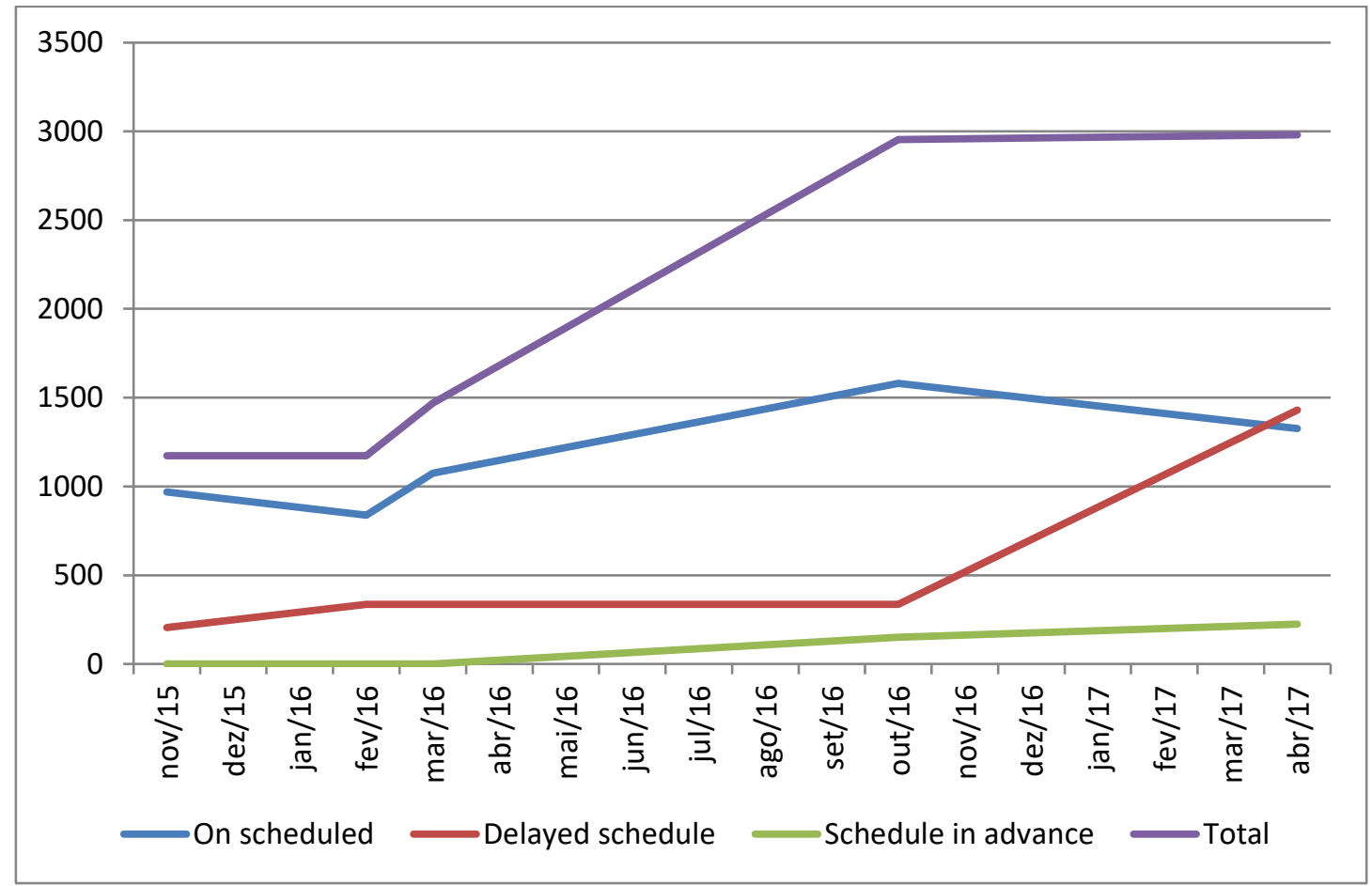

Source: Own elaboration based on ANEEL (2015, 2016a, 2016c, 2016f, 2017d)

From graph 2 it is clear that, even if the number of power plants (and capacity) is rising, schedule is becoming problematic. For the first time, the number and capacity of solar PV power plants with a delayed scheduled has surpassed the power plants on schedule: as of April 2017, the solar PV capacity on schedule and with a delayed schedule are $1326.36 \mathrm{MW}$ and $1430.16 \mathrm{MW}$ respectively. This tendency has no reasonable signs that it will stop in the near future(ANEEL 2017d).

In conclusion, the investments in solar farms are falling short in regards to their viability, commitment to schedule and prevision of the beginning of commercial operation. Expanding such source to $2.65 \mathrm{GW}$ of installed capacity between 2017 and 2018 seems rather unlikely. Even if all capacity with no restrictions to enter into operation when scheduled does commit to it, the expansion would be of less than $1 \mathrm{GW}$ between 2014 (the year of the first auction) and 2018: less than a third of all contracted capacity.It confirms our analysis of an evolution of investments much slower than expected, alongside with performance issues. That jeopardizes the planned expansion of such source and therefore the internalization of the industrial chain: to reach $7 \mathrm{GW}$ of solar PV capacity in 2024, as according to the plan, the source would need to, in the best case scenario, grow more than $600 \%$ in only six years. The only domestic facility capable of providing the necessary PV panels for these enterprises produces 350 MW of PV panels per year maximum. The factory cannot provide for the full planned expansion and there are no signs of new solar PV panel manufacturers planning to install factories in Brazil.

We now analyze the compatibility between the objectives, mechanism and technology in the recent attempted solar expansion in Brazil. 


\section{Compatibility between finance mechanism, funding objectives and technology}

The fact that Brazil disregarded centralized solar power generation until the early 2010's unlike wind power generation, incentivized since the early 2000's, is relevant to this day. Leaving it out of PROEÓLICA and PROINFA ${ }^{31}$ is appointed as one of the various causes for the difference in the development stages of their markets. The structuring and consolidation of a mature PV industrial chain in Brazil is directly linked to the continuity and stability of the demand for PV panels. However, the majority of PV panels in use in the country are imported, and there is only one large national manufacturer $^{32}$ (Ferraz 2014; Nascimento 2015).

Regarding the technical constrains in Brazil, Sekiguchi (2014) addresses the lack of a market that would justify the training and contracting of specialized labor: with no relevant demand there will be no interest in such expenditure. Brazil does not produce solar grade silicon, which intensifies the challenge of internalizing this value chain. Connection to the grid is also considered a technical problem, although its economic consequences are severe ${ }^{33}$. Sitawi and CEBDS (2016) explain that the BNDES' local content policy depends on a persistent demand of these products. In sum, the supply will not settle in unless if the demand is uncertain. Signaling and maintaining solar auctions every year ${ }^{34}$ are necessary measures, but are not enough $^{35}$ for the successful internalization of this technology supply chain(ABSOLAR 2016; Januzzi 2009; Sekiguchi 2014; SITAWI and CEBDS 2016).

Regarding regulatory constraints in Brazil, Jannuzi (2009) and Sekiguchi (2014) do not understand it as neither a barrier nor a facilitator factor. However, the environmental regulation is specifically considered a hindrance because of the non-uniformity between different Brazilian states regarding charters, permits, etc. Nevertheless, in 2015 there were major regulatory and tributary improvements regarding solar PV (Pepitone 2016; SITAWI and CEBDS 2016).

At last, regarding non-regulatory economic constraints in Brazil, the current price of panels makes it less competitive than other sources in Brazil, although all components show signs of reduction of cost internationally. The fact that the national producers are not adequate for the demand of almost $3 \mathrm{GW}$ of utility-level solar PV combined with the fact that imported solar panels are expensive, because of taxes and the exchange rate, impacts even more on the costs. Being the financing of solar power generation by BNDES inspired by the previous wind case, it becomes a hindrance at the start of the process if the national content requirements are too high at first. Also, the BNDES' funds (with smaller interest rates) are a mandatory solution for such problem(EPE 2012; Vazquez 2015; BNDES 2014b, 2014a).

EPE (2012) states that there are three basic conditions for a reasonable promotion of centralized solar PV: specific auctions for this source, more suited contracts; and best suited technical accreditation requirements for PV panels and related equipment. Essentially, its differences and specificities need to be taken into account in order for it to become a viable power source. Without it, solar PV power generation will remain uncompetitive. The institutional learning acquired by the bank in its previous financing of wind power generation (successful regarding the viability of the market and the internalization of parts of the industrial chain) was put to use in the methodology for the financing of solar PV. However, it can be

\footnotetext{
${ }^{31}$ Respectively, "Programa Emergencial de Energia Eólica" and "Programa de Incentivo às Fontes Alternativas de Energia Elétrica" in portuguese, which incentivized wind, run of the river hydro generation and biomass power generation only. Both programs aimed to remedy Brazil's problem with its over-reliance on hydro power generation because of the emergency situation of its dams. Pinto Junior (2007) has more information on Brazil's early 2000's electrical crisis. For more information on the programs, we suggest Podcameni's (2014) review of them.

${ }^{32}$ Reuters (2016) reveals the problems that companies in the market face to start the construction of its solar PV power plants.

${ }^{33}$ It can increase the project cost until it becomes economically unfeasible and unprofitable. Moreover, the only operational solar PV power plants in the country (Fontes Solar I and Fontes Solar II) were constructed near an already operational wind power plant because of lower costs (due to the fact that the connection to the grid is already established) (Enel Green Power 2015).

${ }^{34}$ Which already is not happening, as there were no solar PV capacity contracted throughout 2016.

${ }^{35}$ As such, most agents in this market fear that, an investment in Brazil (regarding factories) will not be concluded in time for it to supply the demand related to the enterprises planned to enter operation in 2017 (SITAWI and CEBDS 2016)
} 
appointed as problematic: it does not acknowledge most differences regarding the characteristics of both sources.

Regarding the scientific and research situations in Brazil, there is a clear gap between wind power and solar power research when comparing Brazil to the rest of the world. The little domestic R\&D can become a hindrance factor if Brazil aims to become a reasonably important (and innovative) player in such market. The solar market in Brazil is still incipient, which, alongside its weak R\&D situation in such area, can restrict a future Brazilian solar industry to a less dynamic and innovative position than other countries that took the lead in such market. Therefore, the country would be left out of the innovative process related to the PV panel industrial chain(Nascimento 2015).

Nevertheless, EPE (2012) was optimistic about the solar insertion in the Brazilian electricity mix:

"Today, large-scale photovoltaic solar energy is not economically competitive with other sources of energy, such as hydro and wind [in Brazil]. However, the analysis of the case of wind energy can be, to some extent, elucidative about the importance of initial stimuli and their impacts on the costs and development of a [new] energy source. [...] In this way, initial stimuli could be traced to make possible the greater penetration of the solar source in the electric mix. Associating these with national industry development policy incentives for the manufacture of equipment for the use of solar energy would be an additional way of boosting this source of competitiveness in the not-too-distant future." ${ }^{36}$ (EPE 2012, 51-52, own translation).

It clearly predicted the growth of solar PV based on the success of the prior success of wind power generation. Similar to BNDES (BNDES 2014a), EPE (2012) was optimistic about the solar expansion in the country, drawing conclusions (and in the case of BNDES, policies) from the prior success of wind power. Although both sources are renewables, the differences between them are enormous and to adapt a methodology from one source to other (with little similarities) made little sense.

We understand that this is the cornerstone of the financing problems regarding the Finem fund and the funding of solar farms. By not respecting the economic and technical differences between both sources, BNDES developed an unsuited mechanism for the financing of solar power generation, as the lack of companies accessing such fund suggests (SITAWI; CDEBS, 2016). We emphasized that there is already contracted demands for solar power generation, with schedules for construction and for entering commercial operation. The lack of financing by BNDES for these projects can be appointed as a major reason for their several delays and high uncertainties regarding its schedule (ANEEL 2016b, 2016f, 2016d, 2016g, 2017a; SITAWI and CEBDS 2016).

Moreover, the Brazilian exchange rate grew steadily since the first auction ${ }^{37}$ (IPEADATA 2017). This made imported PV panels, an option to BNDES' funded domestic panel, an unfeasible possibility. However, it does not impact in the outcome of the mechanism regarding the internalization of the value chain: were the exchange rate low, the companies could easily import solar panels. That changes the outcome of the scenario, as there would probably be more plants under construction, albeit it does not change the fact that the mechanism is not working: it simply would imply a bypass of this problem. Additionally, even if most auction winners are foreign companies, the traditional mechanism is the bank, which means that they entered the auctions counting on such mechanism: using other financing sources is a second best option (for the few companies capable of such, as the Enel group).

BNDES fails to incentivize the internalization of this industrial chain and also hinders the construction and expansion of the solar power generation. The bank fails to achieve its local content objective (industrial policy) and by consequence implies on the failure of the electrical mix objective (its expansion). Therefore, the bank, the regulator and other instances of decision and policy makers have to

\footnotetext{
36 “Assim, hoje a energia solar fotovoltaica de grande porte não é competitiva economicamente com outras fontes de energia, como hídrica e eólica [no Brasil]. No entanto a analise do caso da energia eólica pode ser, em certa medida, elucidativa sobre a importância de estímulos iniciais e seus impactos sobre os custos e o desenvolvimento de uma [nova] fonte de energia. [...] Desta forma, estímulos iniciais poderiam ser traçados para viabilizar a maior penetração da fonte solar na matriz elétrica. Associando-se a esses estímulos políticas de desenvolvimento da indústria nacional para fabricação de equipamentos para aproveitamento da energia solar seria, inclusive, uma forma adicional de alçar essa fonte a competitividade em um futuro não muito distante." (EPE 2012, 51-52)in the original.

${ }^{37}$ Sitawi and CEBDS (2016) expand upon the analysis of the different macroeconomic situations of the start of wind and solar expansions.
} 
decide its objective: to incentivize a local industry of PV panels, a highly concentrated market that would require a serious development plan; or to promote the use of solar source in the country, by allowing and financing imported solar panels. Defining its objective, Brazil can start to work on mechanisms that go accordingly to it and to the technology to be internalized.

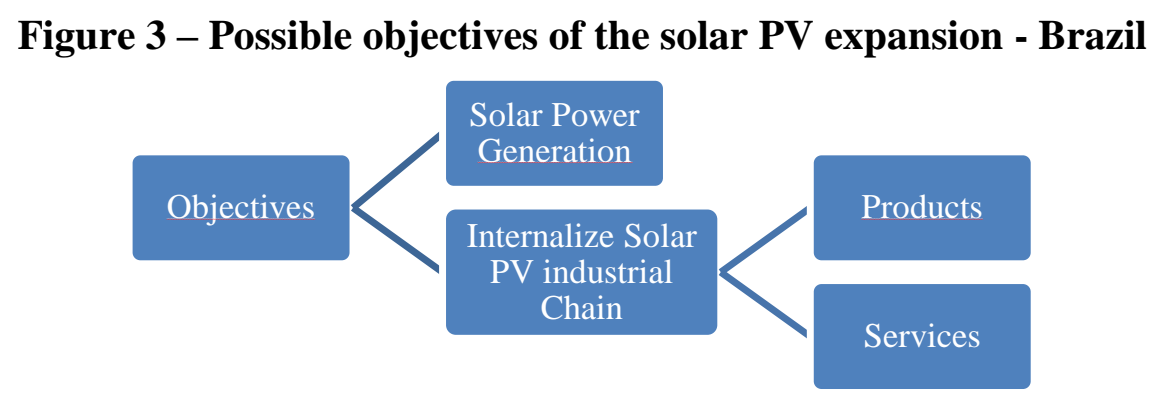

Source: own elaboration

To keep both objectives, BNDES would need to seriously revise its methodology and its access criteria. That would probably incur in the reduction of the $\mathrm{N}$ factors and in a large revision of periods. A possibility would be to focus on assembly and installation of modules as the local content initial incentive, as it is a far less technological demanding step but an important one: in Europe, a large portion of the aggregate value is added on site $^{38}$. According to EPE (2012), about $50 \%$ of the aggregated value of a PV system corresponds to electromechanical components, engineering, assembly and margins of the vendors, added at the installation site. The fact that PV panels are becoming less expensive every year only contributes to this. A focus on services could be a possibility to make the expansion of solar PV likely to happen while internalizing to some degree parts of the value chain related to the source.

In conclusion, $\mathrm{BNDES}^{39}$ needs to revise its methodology. However, first the objectives regarding the expansion of solar PV in Brazil must be more clearly defined, and then the methodology (specially the access criteria) must be changed accordingly to them. If the objectives and mechanisms ignore the fact that solar PV has its own features and traits unlike those of wind power generation and other sources, the expansion and the internalization will be jeopardized. Likewise, if objectives and mechanisms are not compatible, both the expansion and the internalization will be also jeopardized. Therefore, a feasible internalization of the supply chain of solar panels can only be made possible by congruity between objectives (short-term and long-term), mechanisms (including the local content policy and access criteria for public funds) and the technical and economical specificities and characteristics of the source.

\section{Conclusion}

The two tools for promoting renewables in Brazil (auctions and BNDES' financing) are not being capable of successfully promoting the expansion of centralized PV generation in the country. There is currently contracted capacity; however, these power plants are not under construction. The incentive mechanism is not working properly.

Analyzing the several differences between the two sources and addressing the fact that the financing mechanism for solar power generation was heavily inspired by BNDES' prior successful funding of wind farms, the reason of the outcome becomes clear. By not fully acknowledging the many differences between both sources, BNDES underestimated this challenge.

\footnotetext{
38 As an example, in the largest European solar PV power plant, located in France, most of the investment went towards services (assembly, engineering services, irradiation measurement services, etc.), as the CEO of the company responsible for the enterprise, Neoen, Xavier Barbaro states (Reuters 2015).

${ }^{39} \mathrm{We}$ do not address the overreliance of companies on the Finem fund. Again, we stress the problems related to the financing of infrastructure and renewables in Brazil addressed by Vazquez (2015). For more information on the matter, we recommend Vazquez (2016)
} 
We understand that BNDES' objective with its subsidized financing of investments, in this case, is actually two: the promotion of the source in the country; and the internalization of certain parts of the industrial chain. Tackling such challenge with a mechanism heavily influenced by the severely different wind power generation only increased the difficulty.

However, possible solutions for this incompatibility between objective, mechanism and technology can be proposed. BNDES can decide to tackle the hardest challenge that is internalizing a very concentrated industrial chain, requiring a reimagining of this mechanism and the combining of others tools, such as R\&D policies ${ }^{40}$. However, this would probably take more time than planned for the expansion of centralized PV generation in Brazil. If promoting and supporting solar farms is considered the most important objective, then a different shift in the mechanism is needed: imported solar panels will have to be financed to keep schedules intact.

Nevertheless, not all is lost for local content, for, even with imported solar panels (or panels with significantly less local content requirements regarding items), there are ways of promoting income generation in the country and some internalization of the value chain. In Europe, most of the added value comes from services performed at the site of installation: assembly, cabling, engineering services, miscellaneous services, irradiation measurement, etc. For a Brazilian solar PV value chain to flourish, it does not need to necessarily start from either the manufacturing of solar-grade silicon or from the manufacturing of solar modules. A more feasible possibility is to first promote this internalization process through specialized services as means for maturing the solar PV market in the country. With a more mature market in Brazil, the country may then (if coherent with the previously defined objective) start to internalize the industrial chain through progressive local content requirements (regarding items) truly suited for the specificities of solar PV. However, to start this process with a severely underdeveloped solar PV market and an unsuited methodology for the technology is bound to have its problems, as evident from the current status quo. Moreover, the fact that, since 2015, no additional solar capacity was contracted intensifies and corroborates the problem.

The most important conclusion to be drawn from the analysis is that if BNDES and the policy makers persist with their current objectives and mechanisms, the planned expansion of the solar power generation, and in consequence, the implantation of a national industry in this industrial chain will remain highly jeopardized. Brazil has to decide its short-term and long-term objectives for solar and adapt its mechanisms and tools to them while taking into account the specificities of different technologies.

\section{References}

ABSOLAR - Associação Brasileira de Energia Solar Fotovoltaica. 2016. "Energia Solar Fotovoltaica: Potencial, Oportunidades E Desafios.” Audiência pública da comissão mista permanente sobre mudanças climáticas, Brasília, June 15.

Almeida, E. L. F., and R. Bicalho. 2014. “A Nova Energia Do Brasil.” In Como Vai O Brasil: A Economia Brasileira Do Novo Milênio, edited by F. Sá Earp, E. Bastian, and A. Modenesi, 1 ${ }^{\text {a }, ~ 150-80 . ~ R i o ~ d e ~ J a n e i r o: ~ I m a ~ e d i t o r a . ~}$

ANEEL - Agência Nacional de Energia Elétrica. 2015. “Acompanhamento Das Centrais Geradoras Fotovoltaicas Novembro 2015." Acompanhamento Das Centrais Geradoras Fotovoltaicas, November.

. 2016a. "Acompanhamento Das Centrais Geradoras Fotovoltaicas Fevereiro 2016." Acompanhamento Das Centrais Geradoras Fotovoltaicas, February.

2016b. "Novos Empreendimentos (Implantações E Ampliações) Decorrentes de Leilões de Geração (2005 a 2016)."

2016c. “Acompanhamento Das Centrais Geradoras Fotovoltaicas Março 2016.” Acompanhamento Das Centrais Geradoras Fotovoltaicas, March.

. 2016d. "Resultado Dos Leilões."

. 2016e. “Acompanhamento Das Centrais Geradoras Eólicas Outubro 2016.” Acompanhamento Das Centrais Geradoras Fotovoltaicas, October.

2016f. “Acompanhamento Das Centrais Geradoras Fotovoltaicas Outubro 2016.” Acompanhamento Das Centrais Geradoras Fotovoltaicas, October.

2016g. "Resumo Geral Das Usinas."

.2017a. "Banco de Informações de Geração."

. 2017b. "Resumo Geral Das Usinas."

\footnotetext{
${ }^{40}$ As some countries did to internalize wind turbine industrial chains.
} 
2017c. “Acompanhamento Das Centrais Geradoras Eólicas Abril 2017.” Acompanhamento Das Centrais Geradoras Eólicas, April.

. 2017d. “Acompanhamento Das Centrais Geradoras Fotovoltaicas Abril 2017." Acompanhamento Das Centrais Geradoras Fotovoltaicas, April.

Bloomberg. 2016. "Brazil to Boost Funding for Solar, Cut Loans for Coal, Gas." Bloomberg Markets, October 3, sec. News. https://www.bloomberg.com/news/articles/2016-10-03/brazil-to-boost-funding-for-solar-cut-loans-for-coal-and-gas.

BNDES - Banco Nacional de Desenvolvimento Econômico Social. 2012. “Anexo 1: Etapas Físicas E Conteúdo Local Que Deverão Ser Cumpridos Pelo Fabricante.” Financiamentos, Credenciamento de Equipamentos.

. 2014a. "BNDES Define Condições de Apoio a Vencedores de Leilão de Energia Solar E Cria Metodologia Para Fomentar Conteúdo Nacional." BNDES Notícias, sec. Energia.

2014b. "Metodologia Para Credenciamento E Apuração de Conteúdo Local de Equipamentos Fotovoltaicos No Credenciamento de Fabricantes Informatizado - CFI Do BNDES.” Financiamentos, Credenciamento de Equipamentos.

. 2014c. "Perspectivas Da Energia Solar E O Apoio Do BNDES Ao Setor.” presented at the Seminário de Micro e Minigeração Distribuída, April. http://www2.aneel.gov.br/hotsite/mmgd/slides/Antonio\%20Carlos\%20de\%20Andrada\%20Tovar.pdf. 2017a. "BNDES Divulga Novas Políticas Operacionais E Condições de Financiamento.” BNDES Notícias, sec. Institucional. http://www.bndes.gov.br/wps/portal/site/home/imprensa/noticias/conteudo/bndes-divulga-novaspoliticasoperacionais/!ut/p/z0/lY47C8JAEIR_i8WV4RaNrzKoID6wUdBrZE3OuBp3z9wl6r83irVgNwMz34w2eqsNY005Bh LGovE709svhvPJNF7BArrrGJJxpx9v-hOYD9p6ps3vQENol8vRMtfGYThFxEfR2wNn1kcZ1VWRY8RSo4cFBQobZQ4W2L6fkD-DaDz7WYSbVLhYB_hW98T-0Ch-gQLBSe5WgV0daVljwpYGhqhV_DpVZkoGPXXczheU9aL3N3jJg!/.

2017b. "BNDES Finem - Geração de Energia." Financiamentos, detalhe do produto.

Campos Neto, A. C. 2016. "Planos E Programas Dos Setores de Transporte E Energia Elétrica No Brasil Pós-2003.” Texto de Discussão IPEA 2227.

Canadian Solar Inc. 2016. “Canadian Solar Opens Brazil’s Largest Capacity Solar Module Manufacturing Facility.” Canadian Solar Inc News Release, December 12. http://investors.canadiansolar.com/phoenix.zhtml?c=196781\&p=irolnewsArticle \&ID=2228908.

Cleantech Group. 2016. "Clean Energy Patent Growth Index (CEPGI): 2015 Year in Review."

Enel Green Power. 2015. "Enel Green Power Puts Online First Hybrid Plant in Brazil." Enel Green Power Press Release, August 31. https://www.enelgreenpower.com/en/media/press/d201508-enel-green-power-puts-online-first-hybridplant-in-brazil-.html.

EPE - Empresa de Pesquisa Energética. 2012. “Análise Da Inserção Da Geração Solar Na Matriz Elétrica Brasileira.” Nota Técnica EPE, May.

2014. "Plano Decenal de Expansão de Energia 2014."

2016a. "1 LER 2016 Contrata 180,3 MW Em 30 Projetos de PCHs E CGHs.” EPE Imprensa, September 23.

http://www.epe.gov.br/leiloes/Paginas/1\%C2\%BA\%20Leil\%C3\%A3o\%20de\%20Energia\%20de\%20Reserva\%20201 6/1\%C2\%BALER2016contrata180,3MWem30projetos.aspx?CategoriaID=7078.

. 2016b. "Queda de Demanda Por Energia Elétrica Cancela 2 LER 2016." EPE Imprensa, December 16. http://www.epe.gov.br/leiloes/Paginas/2\%C2\%BA\%20Leil\%C3\%A3o\%20de\%20Energia\%20de\%20Reserva\%20201

6\%20-\%20CANCELADO/Quedadedemandaporenergiae1\%C3\%A9tricacancela2\%C2\%BALER2016.aspx.

Eurostat. 2017. "Eurostat Database."

Ferraz, C. 2014. “O Leilão de Reserva E Os Desafios Da Estruturação de Novas Cadeias Produtivas.” Blog Infopetro. October 20.

2015. “Transição Energética E Reforma Do Mercado de Eletricidade.” Blog Infopetro. September 28.

. 2016. "O Avanço Da Energia Solar Fotovoltaica No Brasil: Boas Ou Más Notícias.” Blog Infopetro. September 12.

Ferreira, W. 2013. “O Estado Atual E Os Incentivos Ao Desenvolvimento Da Indústria Eólica Brasileira: O Caso Da Política de Conteúdo Local Do BNDES.” Master’s thesis, Niterói: Universidade Federal Fluminense.

Governo de Pernambuco. 2013. "Pernambuco Promove Primeiro Leilão de Energia Solar Do País, Que Atrai Investimentos de R\$ 597 Milhões.” Notícia Do Site Do Governo de Pernambuco. http://www.pe.gov.br/blog/2013/12/27/pernambucopromove-primeiro-leilao-de-energia-solar-do-pais-que-atrai-investimentos-de-r-597-milhoes/.

Green, R., and I. Staffell. 2016. "Electricity in Europe: Exiting Fossil Fuels?” Oxford Review of Economic Policy 32 (2): 282303.

GTM Research. 2016. "Latin America PV Playbook: Executive Summary Q2 2016 Market Update,” May.

Helm, S., Q. Tannock, and I. Iliev. 2014. "Renewable Energy Technology: Evolution and Policy Implications - Evidence from Patent Literature." WIPO Global Challenges Report.

$\mathrm{Hu}$, Albert Guangzhou, and Gary H. Jefferson. 2009. “A Great Wall of Patents: What Is behind China's Recent Patent Explosion?” Journal of Development Economics 90 (1): 57-68. doi:10.1016/j.jdeveco.2008.11.004.

Huenteler, J., J. Ossenbrink, T. S. Schmidt, and V. H. Hoffmann. 2016. "How a Product's Design Hierarchy Shapes the Evolution of Technological Knowledg —Evidence from Patent Citation Networks in Wind Power." Research Policy 45: 1195-1217. doi:http://doi.org/10.1016/j.respol.2016.03.014. 
IEA - International Energy Agency. 2015. "Renewable Energy Medium-Term Market Report 2015: Market Analysis and Forecasts to 2020."

IPEADATA. 2017. “Ipeadata Database.” http://www.ipeadata.gov.br/Default.aspx.

IRENA - International Renewable Energy Agency. 2016a. "Renewable Energy Benefits: Measuring the Economics." 2016b. "The Power to Change: Solar and Wind Cost Reduction Potential to 2025."

Januzzi, G. M., ed. 2009. Sistemas Fotovoltaicos Conectados À Rede Elétrica No Brasil: Panorama Da Atual Legislação. Campinas: Unicamp.

Joskow, P. L. 2008. "Lessons Learned from Electricity Market Liberalization.” The Energy Journal Special issue.

Mazzucato, M., and C. C. R. Penna. 2015. “The Rise of Mission-Oriented State Investment Banks: The Cases of Germany's KfW and Brazil's BNDES." Working Paper ISI Growth 2015/1 (October). http://www.isigrowth.eu/wpcontent/uploads/2015/11/working_paper_2015_1.pdf. 2016. The Brazilian Innovation System: A Mission-Oriented Policy Proposal. Temas Estratégicos Para O Desenvolvimento Do Brasil 1. Brasília.

MITEI - Massachusetts Institute of Technology Energy Iniciative. 2015. "The Future of Solar Energy: An Interdisciplinary MIT Study."

Nascimento, P. A. M. M. 2015. “Considerações Sobre as Indústrias de Equipamentos Para Produção de Energias Eólica E Solar Fotovoltaica E Suas Dimensões Científicas No Brasil.” Revista Radar 39 (IPEA).

Navigant Research. 2016. "World Wind Energy Market Update 2016."

Pepitone, A. 2016. "Energia Solar Amplia a Característica Sustentável Da Matriz Elétrica Do Brasil." Caderno Opinião - FGV Energia, August.

Pinto Junior, Helder Queiroz Pinto. 2007. “Capítulo 3: Economia da indústria elétrica.” In Economia da energia: fundamentos econômicos, evolução histórica e organização industrial, by Helder Queiroz Pinto Pinto Junior, 1 a , 129-229. Rio de Janeiro: Elsevier.

Podcameni, M. G. 2014. "Sistemas de Inovação E Energia Eólica: A Experiência Brasileira.” PhD Thesis, Rio de Janeiro: Universidade Federal do Rio Janeiro.

PV Magazine. 2016. “Canadian Solar to Invest \$23m in 350 MW Brazil Module Fab.” PV Magazine, June 17. https://www.pvmagazine.com/2016/06/17/canadian-solar-to-invest-23m-in-350-mw-brazil-module-fab_100025057/.

Reuters. 2011. "China Tops U.S., Japan to Become Top Patent Filer.” Technology News, December 21. http://www.reuters.com/article/us-china-patents-idUSTRE7BK0LQ20111221.

2015. "New French Solar Farm, Europe's Biggest, Cheaper than New Nuclear." Reuters, December 1, sec. Commodities. http://www.reuters.com/article/us-climatechange-summit-france-solar-idUSKBN0TK5GW20151201. . 2016. "Usinas Solares Pedem À Aneel Para Adiar Entrega de Energia Em 2 Anos.” O Globo, April 8. http://oglobo.globo.com/economia/usinas-solares-pedem-aneel-para-adiar-entrega-de-energia-em-2-anos-19047765.

Reuters Brasil. 2016. "BNDES Prevê Mais 3 Fabricantes de Painéis Solares No Brasil Até O Final Do Ano." Reuters Brasil, March 30. http://br.reuters.com/article/idBRKCNOWW2ET?pageNumber=1\&virtualBrandChannel=0. 2017a. "Plano Do Brasil Para Energia Solar Avança Devagar E Faz BNDES Estudar Mudanças." Reuters Brasil, January 27. http://br.reuters.com/article/topNews/idBRKBN15B2AN?pageNumber=3\&virtualBrandChannel=0\&sp=true. . 2017b. "BNDES Analisa Financiamentos Para Projetos de Energia Solar.” Reuters Brasil, April 24. http://br.reuters.com/article/businessNews/idBRKBN17Q1MQ-OBRBS.

Sekiguchi, P. M. 2014. “Análise Das Barreiras Para Inserção Da Geração Fotovoltaica Centralizada Na Matriz Elétrica Brasileira.” Specialization Monograph, São Paulo: Universidade de São Paulo.

SITAWI, and CEBDS - Conselho Empresarial Brasileiro para o Desenvolvimento Sustentável. 2016. "Financiamento À Energia Renovável: Entraves, Desafios E Oportunidades."

Tolmasquim, M. 2016. Energia Renovável: Hidráulica, Biomassa, Eólica, Solar, Oceânica. Rio de Janeiro: EPE.

Tomelin, A. C. 2016. "Necessidade de Adaptação Dos Instrumentos de Financiamento de Energia Renovável." Master'sThesis, Rio de Janeiro: Universidade Federal do Rio Janeiro.

Trading economics. 2017. "Interest Rate." http://www.tradingeconomics.com/country-list/interest-rate.

UNEP - United Nations Environment Programme, and EPO - European Patent Office. 2014. "Patents and Climate Change Mitigation Technologies in Latin America and the Caribbean."

US DOE - United States Department of Energy. 2014. "How a Wind Turbine Works." Site.

Vazquez, M. 2015. “As Debêntures de Infraestrutura E O Financiamento de Energia Renovável No Brasil.” Blog Infopetro. September 14.

2016. “O Papel Do Setor Público No Financiamento de Infraestruturas No Brasil.” Blog Infopetro. May 9. 